" 1400 hours: No change.

" 1530 hours: No papilloedema; slight divergent squint noted right. Corneal reflexes present and equal; right arm flaccid, no reflexes present, though grasp reflex elicited. Left arm reflexes and tone normal. Passive movement of the left leg free and associated with crossed extension of the right leg. Tendon reflexes present in both legs_right less than left, plantars both upgoing (no hamstring contraction on the right)."

The man's condition deteriorated; at 1900 hours his respiration rate was $8 / \mathrm{min}$, and so we gave him light premedication, pethidine $100 \mathrm{~g}$ intravenously. Without difficulty the leading medical assistant gave nitrous oxide and oxygen, and I used local lignocaine liberally.

"Burr hole made over the left mid-temporal area, using hand burr 3/4" diameter. Dura exposed and slit. About $20 \mathrm{ml}$ bloodstained cerebrospinal fluid aspirated."

This was part of the description that I offered to the British Military Hospital, but my personal journal affords a more frank statement:

"The patient kept station with survival until 1900 hours. When I got back from dinner he was breathing $8 / \mathrm{min}$ and Cheyne-Stokesing. Death seemed imminent. I said to the leading medical assistant, 'We'd better make a burr hole and see if we can find some blood.' All was ready and the experience seemed less traumatising than had been the setting up of the drip earlier (our Russian colleague had used up every vein there was).

"I kept saying to Sam (leading medical assistant), who gave a very good anaesthetic: 'What the hell am I doing this for? I've never done it before in my life.' After a lot of boring and sweating I delivered what seemed to be a complete disc of temporal bone. Everything bled, the dura was visible... incised ... little or no blood. But things picked up miraculously...."

Later his chest bandaging, which was obviously restricting his breathing, was cut and he coughed up several ounces of putrid sputum, inspissated blood it seemed.

" 3 February. When I was feeling devoid of hope at 0200 hours, a strange thing happened. JS, a third officer from South Africa, came sheepishly to the hospital door. (And this was not in character, being a very colourful person.) 'Do you happen to know Boris's religion?' he asked. Looking at his passport without comprehension, I remarked that religion was something that officialdom did not recognise in Russia. JS wondered if the patient might be a Russian Orthodox and, if so, whether he might have a word with him. Laconically I replied that speech or any communication could not be reciprocated. 'Why do you ask? Are you Catholic?' 'Yes,' he said. 'Then by all means speak to him even if he doesn't comprehend.' JS then asked for a glass of water and disappeared on his own to the patient. He was there only a moment. ... Last rites?"

But Boris, as we all called him, survived and was flown off next morning.

"So off he went. I was weeping as I left the flight deck, partly from relief, but also because of the strangeness of the contact with this small, aesthetic figure. . . He never communicated more than his pain to me and I never knew more than his name. Eugeniy Palamar, born 9 January 1958. The political barrier between us had been neutralised by the more powerful 'brotherhood of the sea' (the captain's quote, not mine)."

Periodically, as our tour of duty changed imperceptibly into a return trip, we had word by signal that Boris gradually improved and was repatriated by air, conscious but with a right hemiplegia.

\section{Where expediency became necessity}

I know that in no circumstances would I have dared to have such surgical adventures within reach of the shores of Great Britain. I would not have dared because my ethical status would have been insecure, and the risks alternative to my anatomical gardening would have seemed trivial. Isolation had translated expediency into necessity. The mother of invention demanded that I put together enough for the patients' survival. The difficult bit was not killing them in the process. For that all credit must go to those teachers of anatomy and surgery who struggled against all the odds to get me through the examinations 40 years ago. The late Professor $\mathrm{H} \mathrm{A}$ Harris, I used to think in those days, put too much emphasis on the importance of the inguinal canal; I had no idea that it was to be my Waterloo. Once I had won there I could tackle anything, so it is as well that I have hung up my tarpaulin jacket, though I miss some excellent shipmates.

\title{
Dose them with water
}

\section{LUIGI PIRANDELLO}

Translated by Elsa Ansley

Do you remember Milocca, blissful little town, so well guarded by its sage administrators that there isn't the slightest danger civilisation might one day reach it? They foresee, with the continuing progress of science, new and ever greater discoveries; and in the meantime they keep Milocca with no running water, no electricity, and no made up roads. Do you remember it?

Well, I want to tell you the latest piece of news from that blissful place, even at the risk of your finding it quite unbelievable. But, otherwise, how can you build up your idea of what is real?

Well then, I have gathered that a certain Calajò is the local general practitioner in Milocca. This doctor seems to enjoy quite a reputation in medical circles (outside the town of course) for his contribution, as they say, to the study of I know not what disease, at present unfortunately still incurable.

But what is the purpose of medical science? To be applied, of course, or so thinks the innocent Dr Calajò. And so, using much discretion and depending on the circumstances, he puts his science into practice, which is, after all, his duty. This is enough to make him disliked by everyone in the town: disliked on principle, quite independently of the outcome of his medications.

To be consistent, the people of Milocca should never summon $\mathrm{Dr}$ Calajò to their dear ones' sick beds. In fact, I have evidence that they don't, until the very last moment-that is, when they stop being Milocca folk and become just poor devils terrified of death approaching. Usually, for minor ailments (or what to begin with they consider minor) they use the services of a certain Piccaglione, who, assisted by a sleep walker with whom he lives, employs some sui generis techniques in treating the sick.

You see, Piccaglione is just the kind of doctor needed in Milocca: he is not qualified; makes no claim to be a scientist; does not have any dealings at all with science, but remains outside it by choice, aided only by that ridiculous somnambulist woman. There is a not inconsiderable advantage in using his services: one doesn't have to go to the chemist, since Piccaglione carries his whole medicine cabinet in his pocket. This is in a box which opens like a book, revealing on either side a number of compartments, each holding a 
small glass bottle full of sugared pills soaked in alcohol containing some homeopathic essence. Five or six of those pills under the tongue and there you are! Assured recovery. Furthermore, because those whom Piccaglione is unable to cure with his little pills are killed, not by him, but by Calajò, curses are heaped upon the latter each and every time he has to be called in.

When he hears these curses upon Dr Calajò, Piccaglione, who is no higher than your elbow but with a great head of hair like so, looks at his tiny hands which perhaps provoke disgust even in him, they are so thin and frail with their pale hairy little fingers resembling caterpillars. He feigns absentmindedness. When they ask him about one thing, he answers about another.

Meanwhile the bells of the eight churches toll for the dead and Calajò hides in his house. Not from fear, of course. He has a clear conscience. Summoned, as usual, at the last moment, he had asked the relatives of the dying man whether they had not called him in by mistake instead of the priest; and had gone back home to continue his studies.

Ah, if the Milocca folk could see where Dr Calajò pursues his studies. In a closed off attic, getting light through an iron grilled eye which, in the musty, stench laden darkness, stares there at the end, dazzlingly.

So as not to be disturbed by the noise of his children, he has placed here a small table with truncated legs; he hops from joist to joist, half bent to avoid bumping his head against the gable roof, and then thrusts his long legs fully out under the small table, sitting on a board placed between two joists, and in that marvellous position he lasts four or five hours, until his wife summons him, either because of a rare visit by somebody sick or because dinner is ready; and then-get up if you can! Those poor legs of his have gone to sleep, tingling and numb from so many hours of immobility.

Often, if the wind along the parapet slightly opens the hatch which is how you get into that dead bit of loft space, the doves and pigeons reared by his wife peep in hesitantly but inquisitively; with frightened cooing noises they move their heads jerkily to get a quick sideways look at him; then turning round off they fly, not before leaving a token of their disapproval. The beams are all encrusted with those disapprovals, but that's the least of it; more sensible is the stench left by cats and also mice, and the aroma of dust and decay that you get in the dampness of permanent shade.

But Calajò doesn't budge: he takes no notice of anything and continues his studies without bothering about either Piccaglione or the folk of Milocca: whether they don't call him in at all, or call him in only at the last moment so that they die like dogs.

However, Milocca also has a chemist on whose shelves the lotions and mixtures, salts, ointments, poisons, and powders all rest in a sleep that often seems eternal.

"Oh, I know, dear Doctor, you speak in this vein because the local authority pays you to be idle, and you find Piccaglione useful. But what about me? You can think about your books; but forgive me, there is an entire population in need of your care; you see them dying with that impostor's little pills in their mouths, and you don't appear to have any scruples or remorse. It is your sacred duty to defend these people, even if they are not asking you to; you must

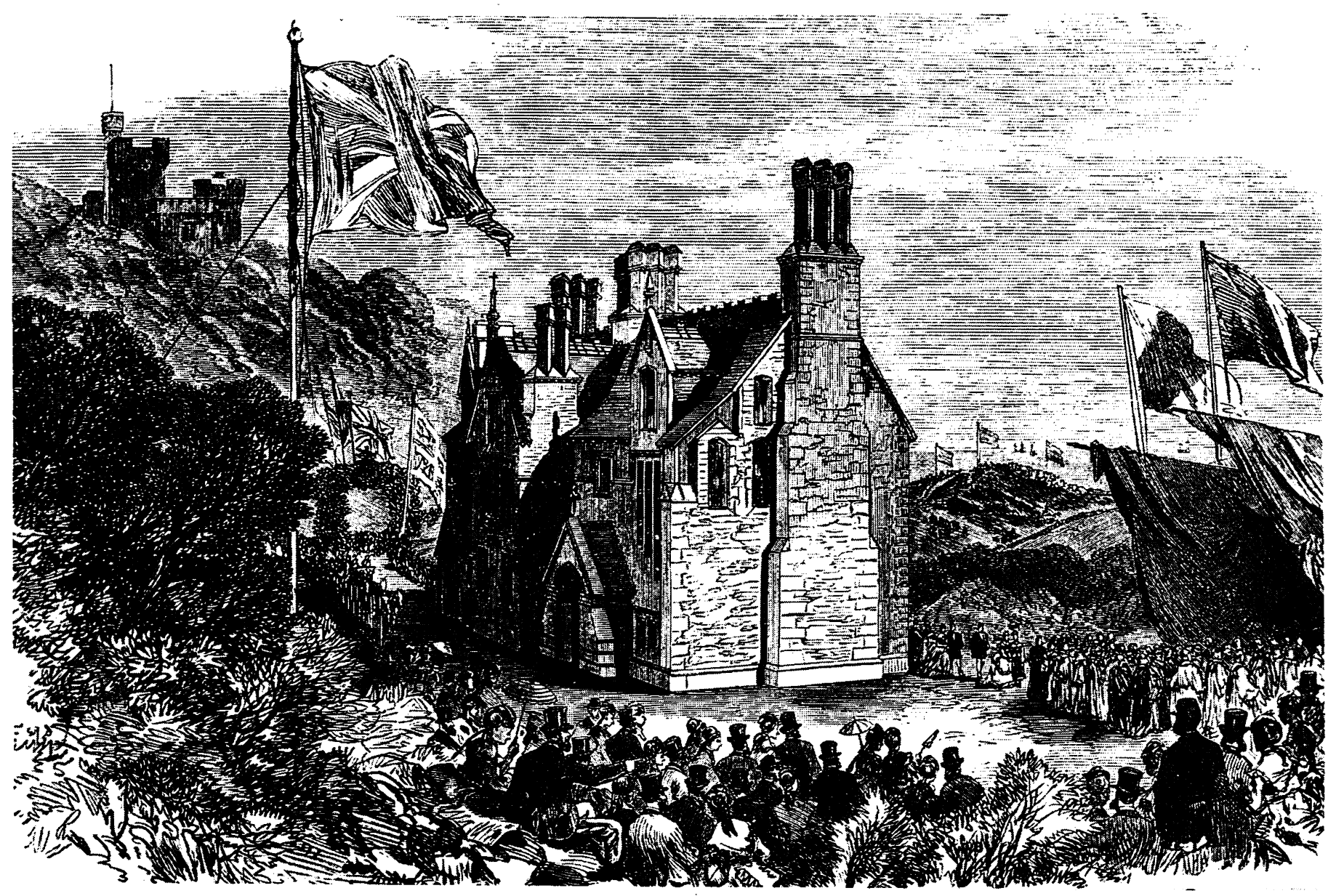

National Cottage Hospital, Ventnor, Isle of Wight (Wellcome Institute Library). 
defend them against his ignorance and his crazy ideas. And I'm not saying this for my own interest!"

Badgered day after day, Dr Calajò finally promised the chemist that he would make a formal denunciation to the authorities to stop Piccaglione practising illegally as a doctor.

Pandemonium! As the news spreads through Milocca of the denunciation, yet to be written, the whole town is in uproar; the mayor, aldermen, members of the council, all furious, rush to $\mathrm{Dr}$ Calajò's house protesting and threatening.

And then Dr Calajò, who for years has let things pass and not said a word to anyone, revolts against the lot of them and, indignant, cries out that although he has not yet written the denunciation, he will certainly now do so, and not only against Piccaglione but also against the mayor and council members, who dare with such arrogance and impudence to protect an impostor.

The matter is becoming serious; ferment in the town is growing hour by hour. And now who should come forward, all calm and smiling, but the manikin with the great head of hair and those revolting, thin hands of his making soft, soft, movements in the air, to recommend prudence and patience.

With such gestures, and quietly as if he knew what he was about, they see him proceed very slowly from the café in the square to his enemy's house. On mounting the steps he takes from his pocket a bundle of pencil written notes; and, as Dr Calajò in person opens the door, before the latter has time to be surprised by his visit, puts in his hand two or three of those notes while lifting a finger to his nose, to convey that he knows a thing or two and to answer him without due thought would be a waste of breath.

"Read them and then act as you please."

Calajò glances at the notes. "My wife?" he exclaims, astonished.

Piccaglione, without batting an eyelid, replies: "For some small gastric trouble suffered by your children."

Dr Calajò clasps his head, and with the expression of one who feels the ground giving way under his feet, repeats: "My wife!"

And Piccaglione: "The last note, you will see, is dated yesterday. Ask her, she cannot deny it. Your children, Doctor, I have never seen, as all consultations, questions, and answers have been in writing, the notes being delivered by your maid, who can testify. Decide then for yourself if you still think it wise to go ahead with the denunciation. The more so since your children-I hope I may be wrong-from the symptoms described by your wife are suffering from scarlet fever. Take care!"

And with these words, Piccaglione turns his back and goes his way. Calajò is left speechless. As soon as he recovers his voice, he calls out: "Lucrezia, Lucrezia!"

A wretched unkempt woman of uncertain age comes rushing out, her eyes dark, heavy, and half closed, as if the lids were weighing her down, one more, the other less. She has narrow shoulders, a hunched back shown up by her faded green bodice: the back of a poor mother worn out by the care of children and home.

She doesn't deny it. Neither denies it or makes any excuse. In fact she should be the one to accuse; because that man, who now cries and wrings his hands in anger, shouting that he has been betrayed by his own wife and holding her responsible for the mortal danger now hanging over the children, perhaps doesn't even know exactly how many children he has, and who was born before or after whom; he never sees them; he doesn't want them at table for meals, since even at table he's reading a book and doesn't like to be disturbed. She could say that she has never mentioned the children's minor ailments for that reason, so as not to trouble him; but she knows it would be a lie and she doesn't say it.

The truth is that she, like all the Milocca folk, and indeed with a deeper and more personal bitterness, dislikes and mistrusts her husband's science; she thinks him dangerous, since it can be only a kind of madness all this obsession with studying, up in that dark attic.

She starts crying desperately, but without a trace of remorse, while he, now in the children's bedroom, after examining their throats, gets up from the small beds where they lie burning with fever, showing signs of the disease all over their little bodies, and starts exclaiming that they are lost, lost, lost.

He must send a telegram immediately to the nearest town and ask for a doctor to come urgently with a supply of Behring serum. Generously he has now stopped his pitiless railing against his wife, and his only thought is to do everything possible to save his children.

But alas, all efforts fail. The two children die, within a few hours of one another; mercifully they die quickly, as do little birds.

And now Dr Calajò has the chance to observe experimentally in himself a most frightening phenomenon: he is aware, quite lucidly, of going mad.

He has the abstract idea of his suffering, that is to say, of the pain of a father at the loss within a few hours of two children; but it seems to him that he really feels nothing, and is crying like an actor on the stage, over the idea of the terrible calamity that has befallen him; he weeps, truly, and feels like a clown, and then guffaws and shouts that it isn't true and he isn't feeling anything.

The young colleague just arrived from the nearby town looks on dismayed and tries to comfort him. Consoling words such as one says though one knows they are of no use.

"And now you will see", exclaims Calajò, “they'll be quite equal to saying I have killed my own children. You don't believe me? Oh yes! They hate me, they hate me because I'm not like them. Here everyone lives in constant expectation of what tomorrow will bring. Here no houses are built because tomorrow, tomorrow who knows in what way houses will be built; no one thinks of installing street lights because tomorrow goodness knows what new method of illumination science will discover, tomorrow! And I, too, should be waiting for tomorrow's treatment of course, for all those who are not actually breathing their last; because when they are, oh, they become cowards then, and want today's treatment, and how they want it!"

"Is that so?" interrupts the young colleague. "And you-forgive me- why don't you start doing medicine as they want it in Milocca? Dose them with water and there you are!"

"What do you mean, dose them with water?" asks Calajò bewildered.

"Yes, renowned colleague," continues the other, "water, mineral water, coloured red or green with syrup of some sort, and there you are!"

Well, this advice, given perhaps to alleviate with a little jest the suffering of the father and the scientist, becomes like a needle in the mind of Dr Calajò, slightly unhinged by the double tragedy. For several days he goes round and round the house like a decapitated fly; but every now and then he stops dead and unexpectedly bursts into peals of ringing laughter. Even at night he sits up in bed to laugh like a madman.

"Dose them with water and there you are! Of course, coloured water."

He will have his revenge. And without any remorse. So they want to die with sweet mouths, the Milocca folk? Dose them with water!

His wife, reduced to a shadow, can find no peace. As soon as she learns that the young doctor, of his own accord, has sent in a denunciation, and that as a result, Piccaglione, without waiting for the official prohibition, has packed his bag and left town with his lady somnambulist, she has a crisis of conscience, and in tortured uncertainty wonders whether it is her duty to warn the citizens of Milocca secretly against her husband, who has become deranged.

This is how things stand at present.

And I'm not sure whether, so far, what has been reported to me as true has seemed to you likely.

The unlikely part, dear sirs, comes now; and it's frankly a shame for medical science. The unlikely part is that the Milocca folk are right.

Because, from the day Dr Calajò, to revenge himself, started prescribing for the sick that "coloured water," the patientsseemingly at death's door-all get better.

Born in 1867, Luigi Pirandello died 50 years ago in December 1936. Best known for his plays (especially Six Characters in Search of an Author and $H e n r y I V$ ), he was also a prolific writer of short stories and novels. The above is a translation of his story Acqua e li (1897). 